\title{
A Rare Occurrence of Hyperkalemia Following Remdesivir: A Case Series
}

\author{
Harsh H. Patel, Sapna D. Gupta, and Supriya D. Malhotra
}

\section{ABSTRACT}

Remdesivir is a nucleoside analog with broad-spectrum antiviral activity against several viruses such as respiratory syncytial virus, Nipah virus, Ebola virus (EBOV), Middle East respiratory syndrome (MERS-CoV), and Severe Acute respiratory Syndrome Coronavirus-1 (SARS-CoV-1). Remdesivir has been used in moderate to severe COVID-19 during the pandemic. Remdesivir is associated with various adverse drug reactions like serum transaminase elevation, nausea, diarrhea, vomiting, poor appetite, gastroparesis, pneumothorax, hypotension, hematuria etc. It has been rarely associated with hyperkalemia. We have reported 3 cases of hyperkalemia following Remdesivir use. In all 3 cases, patients did not have any renal pathology or history of alcohol consumption. Patients were not taking any concurrent medication which increases serum potassium levels with such characteristics seen in our cases. Temporal association was present between hyperkalemia and initiation of Remdesivir in all cases described. Hence, it is very important to be vigilant while prescribing Remdesivir in COVID-19.

Keywords: Adverse drug reaction, hyperkalemia, rare occurrence, remdesivir.

Published Online: October 25, 2021

ISSN: $2736-5476$

DOI: $10.24018 /$ ejclinicmed.2021.2.5.121

H. H. Patel

NHL Municipal Medical College,

Ahmedabad, Gujarat, India.

(e-mail: harsh1hpatel@gmail.com)

S. D. Gupta*

NHL Municipal Medical College,

Ahmedabad, Gujarat, India.

(e-mail: sapna_gupta76@yahoo.com)

S. D. Malhotra

NHL Municipal Medical College,

Ahmedabad, Gujarat, India.

(e-mail: supriyadmalhotra@ gmail.com)

*Corresponding Author

\section{INTRODUCTION}

Remdesivir is a nucleoside analog originally developed against Ebola viruses by Gilead Sciences Inc, a USA based Biopharmaceutical Company. Subsequent evaluation by numerous virology laboratories demonstrated the ability of Remdesivir to inhibit coronavirus replication, including severe acute respiratory syndrome coronavirus 2 (SARSCoV-2) [1]. Remdesivir has a broad-spectrum antiviral activity against several viruses such as respiratory syncytial virus, Nipah virus, Ebola virus (EBOV), Middle East respiratory syndrome (MERS-CoV), and Severe Acute respiratory Syndrome Coronavirus-1 (SARS-CoV-1) [2], [3], [4]. Remdesivir produces its effect by inhibiting the RNA polymerase and integrating it into nascent viral RNA. That leads to two important outcomes such as termination of the viral RNA chain and subsequently inhibits the viral genome replication. As a new disease, SARS-CoV-2 does not have any clinically proven therapeutics. Furthermore, a significant amount of preclinical research was reported in the search for therapeutic treatments for the related viral diseases, severe acute respiratory syndrome (SARS) and Middle East respiratory syndrome (MERS). As the SARS and MERS coronavirus outbreaks did not persist, no therapeutic or vaccine development programs were completed. As a result, drug repositioning and repurposing has received a significant amount of attention [5]. Remdesivir is associated with various adverse drug reactions like serum transaminase elevation, nausea, diarrhea, vomiting, poor appetite, gastroparesis, pneumothorax, hypotension, hematuria etc [6]. Drug-induced hyperkalemia is the most important cause of increased potassium levels in everyday clinical practice [7]. A wide range of drugs can cause hyperkalemia by a variety of mechanisms. Association of Remdesivir with electrolyte disturbances is not a common finding. Here we describe 3 cases of suspected Remdesivir associated hyperkalemia.

\section{OBSERVATIONS}

\section{A. Case Details}

\section{1) Case 1}

A 56 old hypertensive male patient came to emergency medicine department of a tertiary care hospital with chief complaints of fever and difficulty in breathing for 1 day. Patient was tested COVID-19 positive by RTPCR. Patient was not taking any concomitant medication at the time of admission. Patient did not have history of alcohol consumption. On admission patient was conscious and well oriented with normal temperature, Pulse: $88 / \mathrm{min}$, BP: 140/84 $\mathrm{mmHg}$, Respiratory rate: $22 / \mathrm{min}, \mathrm{SPO} 2: 99 \%$ on NRBM $15 \mathrm{~L} / \mathrm{min}$. CT severity score of the patient was $17 / 25$. patient was categorized as having severe COVID-19.

Initial laboratory findings included: $\mathrm{Hb}: 15.3 \mathrm{~g} / \mathrm{dl}(12-18)$, WBC: $8.09 \mathrm{kU} / \mathrm{L}$ (5.2-12.4), RBC: $5.09 \mathrm{M} / \mathrm{mcL}$ (4.5-5.5), Platelet count: $112 \mathrm{kU} / \mathrm{L}(130-400)$, CRP: $221.14 \mathrm{mg} / \mathrm{L}(<5)$, ESR: $84 \mathrm{~mm} / \mathrm{hr}(0-15)$, D-Dimer: $1.84 \mu \mathrm{g} / \mathrm{ml}(<0.5)$, Blood Urea: $31.3 \mathrm{mg} / \mathrm{dL}$ (15-45), Serum Creatinine: $1.3 \mathrm{mg} / \mathrm{dL}$ (0.71.3), Serum Sodium: $142 \mathrm{mmol} / \mathrm{L}$ (132-146), Serum Potassium: $4.6 \mathrm{mmol} / \mathrm{L}$ (3.5-5.5), SGPT: $41 \mathrm{U} / \mathrm{L}$ (10-49), 
SGOT: 58 U/L (0-34), Alkaline Phosphatase (ALP): 118 U/L (45-129).

On admission patient was prescribed Inj. Remdesivir $200 \mathrm{mg}$ IV OD, Inj. Ceftriaxone $1 \mathrm{gm} \mathrm{IV} \mathrm{BD,} \mathrm{Tab.}$ Azithromycin $500 \mathrm{mg}$ OD, Inj. Low molecular weight Heparin 0.6 cc SC BD, Inj. Dexamethasone8 mg IV TDS, Levosalbutamol $1.25 \mathrm{mg}$ - Ipratropium bromide $500 \mathrm{mcg}$ respule TDS, Inj. Pantoprazole $40 \mathrm{mg}$ IV BD, Inj. Ondansetron $4 \mathrm{mg}$ IV TDS, Tab vit C. $500 \mathrm{mg}$ PO TDS, Tab Multivitamins PO OD.

On admission Serum potassium level was normal ( $4.6 \mathrm{mmol} / \mathrm{L})$. Serum potassium levels started increasing on day 4 of initiating Inj. Remdesivir. It increased from $4.9 \mathrm{mmol} / \mathrm{L}$ on day 3 to $5.5 \mathrm{mmol} / \mathrm{L}$ on day 4 and $6.2 \mathrm{mmol} / \mathrm{L}$ on day 5 . Then it remained high until day 11 of admission. Inj. human Insulin (regular) with $25 \%$ dextrose solution was administered. Serum potassium level came back to normal level on day $12(4.9 \mathrm{mmol} / \mathrm{L})$ and did not increase after that. This suspected ADR was reported to PVPI with unique ID no IN-IPC-30054904.

\section{2) Case 2}

A 68-year-old hypertensive female patient was tested positive for COVID-19 by RTPCR and was admitted to tertiary care hospital. Patient was not taking any concomitant medication at the time of admission. Patient did not have history of alcohol consumption. Her CT severity score was $16 / 25$. On admission patient was conscious and well oriented with normal temperature, Pulse: 98/min, BP: 124/82 mmHg, Respiratory rate: $20-24 / \mathrm{min}$, SPO2: $96 \%$ on NRBM at $8 \mathrm{~L} / \mathrm{min}$. patient was categorized as having severe COVID19.

Initial laboratory findings included: $\mathrm{Hb}: 11.6 \mathrm{~g} / \mathrm{dl}$ (12-18), WBC: $5.46 \mathrm{kU} / \mathrm{L}$ (5.2-12.4), RBC: $4.37 \mathrm{M} / \mathrm{mcL}$ (4.5-5.5), Platelet count: $133 \mathrm{kU} / \mathrm{L}(130-400)$, CRP: $26.57 \mathrm{mg} / \mathrm{L}(<5)$, ESR: $50 \mathrm{~mm} / \mathrm{hr}(0-15)$, D-Dimer: $0.91 \mu \mathrm{g} / \mathrm{ml}(<0.5)$, Blood Urea: $48.8 \mathrm{mg} / \mathrm{dL}$ (15-45), Serum Creatinine: $1.03 \mathrm{mg} / \mathrm{dL}$ (0.7-1.3), Serum Sodium: $140 \mathrm{mmol} / \mathrm{L}$ (132-146), Serum Potassium: $5.5 \mathrm{mmol} / \mathrm{L}$ (3.5-5.5), SGPT: $47 \mathrm{U} / \mathrm{L}$ (10-49), SGOT: 74 U/L (0-34), Alkaline Phosphatase (ALP) : 72 U/L (45-129).

On admission patient was prescribed Inj. Remdesivir $200 \mathrm{mg}$ IV OD, Inj. Ceftriaxone 1 gm IV BD, Tab. Azithromycin $500 \mathrm{mg}$ OD, Levosalbutamol $1.25 \mathrm{mg}-$ Ipratropium bromide $500 \mathrm{mcg}$ respule TDS, Inj. Pantoprazole $40 \mathrm{mg}$ IV BD, Inj. Ondansetron $4 \mathrm{mg}$ IV TDS, Tab vit C. $500 \mathrm{mg}$ PO TDS, Tab Multivitamins PO OD.

On admission Serum potassium level was on borderline high (5.5). It started increasing on day 2 of initiating Inj. Remdesivir. It increased from $5.5 \mathrm{mmol} / \mathrm{L}$ on day 1 to $6 \mathrm{mmol} / \mathrm{L}$ on day 2 and it remained high until day 4 of admission. Inj. human Insulin (regular) with $25 \%$ dextrose solution was administered. Serum potassium level came back to normal level on day $5(5.1 \mathrm{mmol} / \mathrm{L})$ and did not increase after that. This suspected ADR was reported to PVPI with unique ID no IN-IPC-300551300.

\section{3) Case 3}

A 49 old male patient came to emergency medicine department of a tertiary care hospital with chief complains of fever, cough and difficulty in breathing for 3 days. Patient was tested COVID-19 positive by RTPCR. Patient did not have any comorbidities and was not taking any concomitant medication at the time of admission. Patient did not have history of alcohol consumption. On admission patient was conscious and well oriented with normal temperature, Pulse: 78/min, BP: $126 / 80 \mathrm{mmHg}$, Respiratory rate: $24 / \mathrm{min}$, SPO2: $92 \%$ on room air. $\mathrm{X}$ ray findings revealed bilateral ground glass opacities. patient was categorized as having moderate severity for COVID-19.

Initial laboratory findings included: $\mathrm{Hb}: 13.8 \mathrm{~g} / \mathrm{dl}$ (12-18), WBC: $8.74 \mathrm{kU} / \mathrm{L}$ (5.2-12.4), RBC: $4.56 \mathrm{M} / \mathrm{mcL}$ (4.5-5.5), Platelet count: $217 \mathrm{kU} / \mathrm{L}(130-400)$, CRP: $58 \mathrm{mg} / \mathrm{L}(<5)$, DDimer: $0.68 \mu \mathrm{g} / \mathrm{ml}(<0.5)$, Blood Urea: $15 \mathrm{mg} / \mathrm{dL}(15-45)$, Serum Creatinine: $0.9 \mathrm{mg} / \mathrm{dL}(0.7-1.3)$, Serum Sodium: 140 mmol/L (132-146), Serum Potassium: 4.5 mmol/L (3.55.5), SGPT: 37 U/L (10-49), SGOT: 32 U/L (0-34), Alkaline Phosphatase (ALP): 57 U/L (45-129).

On admission patient was prescribed Tab. Azithromycin $500 \mathrm{mg}$ OD, Inj. Remdesivir $200 \mathrm{mg}$ IV OD, Inj. Dexamethasone $8 \mathrm{mg}$ IV TDS, Inj. Low molecular weight Heparin 0.6 cc SC BD, Syrup Codeine (10 mg/5 ml)Triprolidine $(1.25 \mathrm{mg} / 5 \mathrm{ml}) 2$ TSP TID, Inj. Pantoprazole 40 mg IV BD, Inj. Ondansetron 4 mg IV TDS, Tab vit C. 500 mg PO TDS, Tab Multivitamins PO OD.

On admission Serum potassium level was normal (4.5 $\mathrm{mmol} / \mathrm{L}$ ). Serum potassium levels increased on third day of initiating Inj. Remdesivir. It increased from $4.5 \mathrm{mmol} / \mathrm{L}$ on day 2 to $5.9 \mathrm{mmol} / \mathrm{L}$ on day 3. Inj. human Insulin (regular) with $25 \%$ dextrose solution was administered. Serum potassium level came back to normal level on day 4 (4.6 $\mathrm{mmol} / \mathrm{L})$ and did not increase after that. This suspected ADR was reported to PVPI with unique ID no IN-IPC-300551375.

\section{DISCUSSION}

Hyperkalemia is defined as a serum potassium level above the normal range, and various arbitrary cutoffs, such as $>5.0$, $>5.5$ or $>6.0 \mathrm{mmol} / 1$, are used to denote different levels of severity [8]. In hospitalized patients, the incidence of hyperkalemia ranges from 1.3 to $10 \%$, with a mortality rate of 1 per 1,000 patients. Drugs have been identified as a primary cause or contributing factor of hyperkalemia in 35$75 \%$ of hospitalized patients [7]. A wide range of drugs can cause hyperkalemia (Table I).

Hyperkalemia is not common following Remdesivir use. In all cases we reported, clinically significant hyperkalemia has been seen. In case 1 serum potassium levels increased on day 4 (5.5 mmol/L) of initiating Inj. Remdesivir and remained high until day 11 of admission. Serum potassium level came back to normal level on day $12(4.9 \mathrm{mmol} / \mathrm{L})$ (Fig. 1). In case 2 serum potassium levels started increasing on day 2 (6 mmol//L) of initiating Inj. Remdesivir and it remained high until day 4 of admission. Serum potassium level came back to normal level on day $5(5.1 \mathrm{mmol} / \mathrm{L})$. In case 3 serum potassium levels increased on day $3(5.9 \mathrm{mmol} / \mathrm{L})$ of initiating Inj. Remdesivir. Serum potassium level came back to normal level on day $4(4.6 \mathrm{mmol} / \mathrm{L})$.

TABLE I: LIST OF DRUGS KNOWN TO CAUSE HYPERKALEMIA 


\begin{tabular}{|c|c|c|c|}
\hline $\begin{array}{l}\text { Drug-inducing } \\
\text { transmembrane } \\
\text { potassium } \\
\text { movement }\end{array}$ & $\begin{array}{l}\text { Drugs that } \\
\text { affect } \\
\text { aldosterone } \\
\text { secretion }\end{array}$ & $\begin{array}{l}\text { Drug that } \\
\text { causes tubular } \\
\text { resistance to the } \\
\text { action of } \\
\text { aldosterone }\end{array}$ & $\begin{array}{l}\text { Potassium- } \\
\text { sparing } \\
\text { diuretics }\end{array}$ \\
\hline $\begin{array}{c}\text {-Beta blockers } \\
\text {-Digoxin } \\
\text { intoxication } \\
\text {-Intravenous } \\
\text { cationic amino } \\
\text { acids } \\
\text {-Mannitol } \\
\text {-Suxamethonium } \\
\text {-Verapamil }\end{array}$ & $\begin{array}{c}\text {-ACE } \\
\text { inhibitors } \\
\text {-ARBs } \\
\text {-Direct renin } \\
\text { inhibitors } \\
\text {-NSAIDs } \\
\text {-Calcineurin } \\
\text { inhibitors }\end{array}$ & $\begin{array}{l}\text {-Aldosterone } \\
\text { antagonists } \\
\text {-Potassium- } \\
\text { sparing diuretics } \\
\text {-Trimethoprim } \\
\text { pentamidine }\end{array}$ & $\begin{array}{c}\text {-Salt } \\
\text { substitutes } \\
\text { and salt } \\
\text { alternatives } \\
\text {-penicillin G } \\
\text {-stored blood } \\
\text { products }\end{array}$ \\
\hline
\end{tabular}

In case 1 serum potassium remained high for 7 days while in case 2 it remained high for 3 days and in case 3 it remained high for 1 day. This can be due to the reason that Remdesivir has an elimination half-life of 1 hour following a single 30minute intravenous infusion. Under the same conditions, the elimination half-lives of the Remdesivir metabolites GS441524 and GS-704277 are 27 hours and 1.3 hours, respectively [9]. Remdesivir was continued in best interest of patient and on physician's discretion. Patient was treated with Inj. human Insulin (regular) with 25\% dextrose solution for hyperkalemia. There are many interventions available to treat hyperkalemia like calcium gluconate, sodium bicarbonate, insulin (regular), beta-2 receptor agonists, furosemide etc.

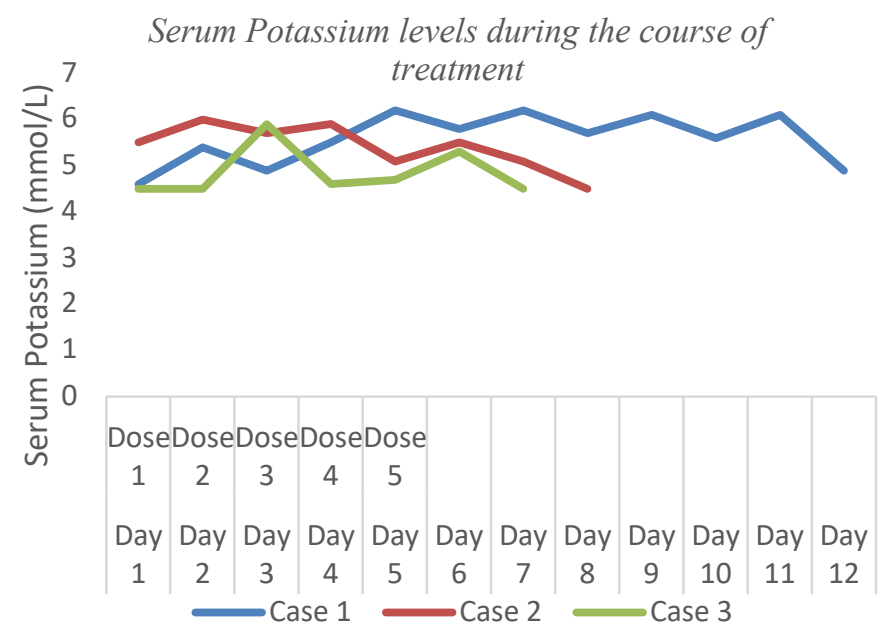

Fig. 1. Serum potassium levels during the course of treatment.

In all cases we reported, patients did not have any renal pathology or history of alcohol consumption. Patients were not taking any concurrent medication which could increase serum potassium levels with such characteristics seen in our cases. Serum potassium level increased suddenly after initiation of Remdesivir, which suggests temporal relationship between Remdesivir and serum potassium rise.

Hyperkalemia is a serious medical condition. In current medical literature, hyperkalemia following Remdesivir use has been scarcely mentioned. WHO solidarity trial and UK recovery trial showed that Remdesivir failed to show any measurable benefit in mortality or disease course of COVID19 [10], [11]. Hence, physicians should be vigilant about possible adverse drug reactions while prescribing Remdesivir and use of Remdesivir should not be a knee jerk reaction in COVID-19.

\section{REFERENCES}

[1] R. T. Eastman, J. S. Roth, K. R. Brimacombe, A. Simeonov, M. Shen, S. Patnaik and M. D. Hall, "Remdesivir: a review of its discovery and development leading to emergency use authorization for treatment of COVID-19." ACS central Science 4;6(5):672-83, 2020.

[2] M. K. Lo, R. Jordan and A. Arvey, "GS-5734 and its parent nucleoside analog inhibit filo-, pneumo-, and paramyxoviruses.” Sci Rep 7:43395, 2017.

[3] T. P. Sheahan, A. C. Sims and R. L. Graham, "Broad-spectrum antiviral GS5734 inhibits both epidemic and zoonotic coronaviruses." Sci Transl Med 9(396), 2017.

[4] M. L. Agostini, E. L. Andres, A. C. Sims, R. L. Graham, T. P. Sheahan, X. Lu, E. C. Smith, J. B. Case, J. Y. Feng, R. Jordan and A. S. Ray, "Coronavirus susceptibility to the antiviral remdesivir (GS-5734) is mediated by the viral polymerase and the proofreading exoribonuclease." MBio 6;9(2):e00221-18, 2018.

[5] J. S. Morse, T. Lalonde, S. Xu and W. R. Liu, "Learning from the past: possible urgent prevention and treatment options for severe acute respiratory infections caused by 2019-nCoV." Chembiochem 21(5):730-8, 2020.

[6] Q. Fan, B. Zhang, J. Ma and S. Zhang, "Safety profile of the antiviral drug remdesivir: An update." Biomedicine \& Pharmacotherapy 130:110532, 2020.

[7] C. Ben Salem, A. Badreddine, N. Fathallah, R. Slim and H. Hmouda "Drug-induced hyperkalemia.” Drug Saf 37(9):677-92, 2014.

[8] C. P. Kovesdy, "Management of hyperkalemia in chronic kidney disease." Nat Rev Nephrol 10(11), 653, 2014.

[9] Bethesda (MD): National Library of Medicine (US), National Center for Biotechnology Information; 2004-. PubChem Compound Summary for CID 121304016, Remdesivir; [cited 2021 June 6]. Available from: https://pubchem.ncbi.nlm.nih.gov/compound/Remdesivir/.

[10] H. Pan, R. Peto, Q. A. Karim, M. Alejandria, A. M. H. Restrepo, C. H. Garcia and M. P. Preziosi, "Others, Repurposed antiviral drugs for COVID-19; interim WHO SOLIDARITY trial results.” medRxiv 2020.

[11] J. Beigel, K. Tomashek, L. E. Dodd, A. K. Mehta, B. S. Zingman, A. C. Kalil and C. H. Lane, "Remdesivir for the treatment of Covid-19final report." N Engl J Med 2020.

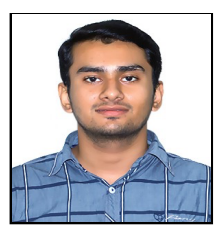

Harsh H. Patel was born in Gujarat, India in 1995. He had done his Bachelor of Medicine and Bachelor of Surgery (M.B.B.S) degree from Government Medical College, Baroda, Gujarat, India in 2019. $\mathrm{He}$ is now Pursuing his M.D in Pharmacology at Smt. NHL Municipal Medical College, Ahmedabad, India. 